\title{
POZIOM DZIALALNOŚCI INNOWACYJNEJ MIKROPRZEDSIĘBIORSTW FUNKCJONUJACYCH W INTELIGENTNYCH SPECJALIZACJACH - PERSPEKTYWA WOJEWÓDZTWA WARMIŃSKO-MAZURSKIEGO
}

https://doi.org/10.33141/po.2019.01.05

Kamil Decyk

\author{
Przegląd Organizacji, Nr 1 (948), 2019, ss. 35-42 \\ www.przegladorganizacji.pl \\ CTowarzystwo Naukowe Organizacji i Kierownictwa
}

\section{Wprowadzenie}

W obliczu zaprezentowanej problematyki badawczej związanej $\mathrm{z}$ działalnością innowacyjną oraz inteligentnymi specjalizacjami, interesujące jest to, $\mathrm{w}$ jaki sposób prosperują podmioty zaliczane do branż o „kluczowym znaczeniu” w rozwoju regionów. Czy faktycznie wśród nich należy poszukiwać przedsiębiorstw, które mogą stanowić o dynamice i o zwiększonym rozwoju gospodarki regionalnej? W związku z tak przedstawionym problemem badawczym w opracowaniu za cel badań przyjęto ocenę poziomu działalności innowacyjnej mikroprzedsiębiorstw (jako najliczniejszej grupy podmiotów gospodarki narodowej i regionalnej) prosperujących w inteligentnych specjalizacjach. W nawiązaniu do zaprezentowanego celu na potrzeby opracowania sformułowano hipotezę badawczą, zakładającą, że poziom działalności innowacyjnej mikroprzedsiębiorstw w inteligentnych specjalizacjach Warmii i Mazur jest wyższy niż ten reprezentowany przez podmioty mikro z całej Polski (badania prowadzone przez Tarnawę w PARP).

\section{Metoda badawcza}

D o realizacji celu badawczego, a także do weryfikacji postawionej hipotezy wykorzystano trzy metody badawcze. Pierwsza z nich to metoda pomiaru sondażowego polegająca na pozyskaniu od respondenta pożądanych informacji z wykorzystaniem techniki obserwacji w postaci zarówno wywiadu bezpośredniego (osobisty, telefoniczny), jak i pośredniego - korespondencyjnego (Szreder 2004, s. 148). Podczas stosowania metody pomiaru sondażowego jako narzędzie pomiarowe wykorzystywano autorski kwestionariusz ankietowy. Składał się on z trzech głównych części: charakterystyki ogólnej badanego podmiotu, jego poziomu innowacyjności, a także wewnętrznych i zewnętrznych uwarunkowań działalności innowacyjnej. W zakresie celu badawczego przyjętego $\mathrm{w}$ opracowaniu respondenci identyfikowali innowacje oraz wskazywali stopień i skalę ich nowości. W badaniach zastosowano również metodę analizy piśmiennictwa, w ramach której dokonano przeglądu

piśmiennictwa zagranicznego, jak też krajowego w zakresie omawianej problematyki (m.in. działalności innowacyjnej czy inteligentnych specjalizacji). Wykorzystana została ona po pierwsze do wskazania najważniejszych aspektów teoretycznych związanych z poruszaną tematyką, a po drugie stanowiła podstawę przy projektowaniu i planowaniu badań oraz opracowaniu ich wyników. Przy zastosowaniu metody analizy piśmiennictwa wyróżniono cztery rodzaje innowacji. Zaliczono do nich zarówno zmiany technologiczne (produktowe i procesowe), jak i nietechnologiczne (organizacyjne i marketingowe). W zakresie pierwszej $\mathrm{z}$ wymienionych grup innowacji w badaniu uwzględniono oprócz zupełnych nowości również ulepszenia. Poziom nowości wdrażanych innowacji został określony natomiast $\mathrm{w}$ zakresie od: „nowości w skali samej firmy” do „nowości w skali europejskiej/światowej”. Ostatnią metodą zastosowaną w badaniach była metoda porównawcza, która posłużyła do wskazania różnic i podobieństw w wynikach uzyskanych w badaniach własnych oraz w ogólnopolskich badaniach działalności innowacyjnej mikroprzedsiębiorstw realizowanych przez PARP w 2015 r. Porównywanie w metodzie tej „pozwala orzekać o tożsamości całkowitej lub cząstkowej” i dotyczy aspektów porównywalnych ze sobą, a na ich podstawie umożliwia formułowanie dalszych wniosków. Pozwala także na pełniejszą interpretację omawianej problematyki (Kurek-Kokocińska, 2002, s. 53; Pieter, 1967, s. 317).

$\mathrm{Na}$ weryfikację postawionej hipotezy badawczej, a także na realizację założonego celu pozwoliły wyniki badań przeprowadzonych w latach 2012-2014 na reprezentatywnej grupie 382 mikroprzedsiębiorstw $\mathrm{z}$ branż kluczowych w rozwoju województwa warmińsko-mazurskiego'. Ustalono je z wykorzystaniem metody studiów literaturowych. Przyporządkowania do najważniejszych branż dokonano na podstawie RSI Województwa Warmińsko-Mazurskiego oraz bazując na badaniach prowadzonych przez podmioty lokalne. Dobór próby miał charakter nielosowy. Wśród mikroprzedsiębiorstw objętych badaniami znalazły się m.in. podmioty prosperujące $\mathrm{w}$ inteligentnych 
specjalizacjach regionu Warmii i Mazur, za które zgodnie $\mathrm{z}$ raportem Ministerstwa Infrastruktury (Wspólne obszary ..., 2015, s. 1) dotyczącym województw Polski Wschodniej uznano trzy obszary:

- żywność wysokiej jakości - produkcja i przetwórstwo żywności, rozwój specjalizacji przez wykorzystanie walorów ekologicznych regionu,

- meblarstwo i przemysł drzewny - firmy, w których podstawowym surowcem jest drewno, zarówno podmioty przetwórcze, producenci, jak i sprzedawcy mebli, rozwój specjalizacji przez stosowanie nowego wzornictwa, a także wdrażanie innowacyjnych technologii,

- ekonomia wody, w której rozwój specjalizacji następuje przez zrównoważone wykorzystanie wody z poszanowaniem jej zasobów naturalnych.

Inteligentne specjalizacje łącznie reprezentowały 164 mikroprzedsiębiorstwa spośród wszystkich 382, co stanowiło $42,9 \%$ podmiotów $\mathrm{z}$ całej próby. Wśród nich najliczniej reprezentowane były mikroprzedsiębiorstwa $\mathrm{z}$ branży spożywczej - 42,1\%, drugie pod względem liczności były firmy prosperujące $\mathrm{w}$ sektorze turystycznym - 32,3\%, zaś co piąta organizacja była przedstawicielem sektora drzewno-meblarskiego - 25,6\%. Mikroprzedsiębiorstwa uczestniczące $\mathrm{w}$ badaniu reprezentowały $\mathrm{w}$ większości podregion olsztyński - 66,46\%. W województwie warmińsko-mazurskim wyróżnia się jeszcze dwa podregiony: elbląski oraz ełcki. W badaniu $\mathrm{z}$ wymienionych obszarów uczestniczyło odpowiednio: 23,17 oraz $10,37 \%$ podmiotów. Spośród 164 mikrofirm reprezentujących inteligentne specjalizacje Warmii i Mazur zdecydowanie najwięcej prowadzonych było $\mathrm{w}$ formie indywidualnej działalności gospodarczej - 80,5\%. Drugą co do popularności formą prowadzenia działalności wśród badanych jednostek była spółka cywilna 14,0\%. Pozostałe formy prawne reprezentowane były przez nieznaczny odsetek przedsiębiorstw (np. spółka z o.o. czy spółka jawna, obie po 1,8\%).

Nawiązując do wcześniejszych rozważań teoretycznych, działalność innowacyjną interpretowano w badaniach jako aktywność, w wyniku której innowacje kończyły się sukcesem, a więc były uznawane za jej rezultat. W perspektywie tak rozumianej aktywności związanej z innowacjami wykreowało się pojęcie przedsiębiorstwa innowacyjnego, za które w badaniach uznano podmiot, który w ostatnich trzech latach wdrożył innowację technologiczną w formie nowego lub ulepszonego produktu/procesu albo zastosował po raz pierwszy w swojej działalności zmianę nietechnologiczną (innowację marketingową lub organizacyjną). Taka interpretacja zgodna jest z podejściem prezentowanym w najnowszym podręczniku Oslo Manual.

\section{Działalność innowacyjna w inteligentnych specjalizacjach - ujęcie teoretyczne}

W kontekście problematyki związanej z zagadnieniami dotyczącymi innowacyjności należy odnieść się do J.A. Schumpetera (1960), który pojęcie innowacji po raz pierwszy wprowadził do nauk ekonomicznych na początku XX w. W koncepcji, którą prezentował, innowacje związane były wyłącznie $\mathrm{z}$ działalnością prowadzoną przez przedsiębiorstwa przemysłowe, które stanowiły podstawę gospodarki kapitalistycznej początku wieku XX. Zgodnie z poglądem J.A. Schumpetera (1995, s. 102), ich działalność innowacyjna stanowiła istotę procesu „nieustannego rewolucjonizowania od środka struktury gospodarczej, nieustannego burzenia starej i ciągłego tworzenia nowej (struktury), (...) procesu twórczego burzenia o zasadniczym znaczeniu dla kapitalizmu”.

Działalność innowacyjna często utożsamiana jest $\mathrm{z}$ innowacjami, które można interpretować z perspektywy procesów. W takiej konwencji aktywność ta interpretowana jest przez E. Stawasza i D. Niedbalską (2011, s. 54) jako działania w zakresie czynności niezbędnych do powstania i praktycznego zastosowania nowych rozwiązań. W. Janasz i K. Kozioł (2007, s. 33) interpretują ją natomiast jako sekwencję logicznie następujących po sobie zdarzeń, począwszy od powstania pomysłu w formie inwencji, lub wynalazku przez kontynuowanie tzw. „ucieleśnienie” (rozumiane jako innowacja), aż po upowszechnienie. W podręczniku zawierającym podstawy metodologiczne $\mathrm{z}$ obszaru innowacyjności działalność innowacyjną określa się natomiast jako wszelkie działania rozwojowe finansowe oraz komercyjne, także zaniechane przez firmę, które są podejmowane $\mathrm{z}$ uwagi na wprowadzanie innowacji (Oslo Manual, 2018, s. 33, 68). W kontekście tej definicji interesujące sa dwa fakty. Po pierwsze, działalność innowacyjna jest pojęciem obszerniejszym niż innowacja. Podczas identyfikacji jej poziomu możliwa jest estymacja bazująca nie tylko na analizie nowych i istotnie ulepszonych rozwiązań (ich implementacji, jakości, poziomie), ale również na podstawie działań ukierunkowanych na ten cel niekoniecznie zakończonych sukcesem (innowacją). De facto, podczas oceny poziomu działalności innowacyjnej danego przedsiębiorstwa może okazać się, że nie jest ono autorem żadnej innowacji zakończonej sukcesem - wdrożonej bez względu na jej komercyjny wynik, a jedynie wykazuje aktywność w zakresie działalności (Manual Oslo, 2005, s. 59):

- kontynuowanej, która może w przyszłości zakończyć się wdrożeniem nowych lub istotnie ulepszonych rozwiązań,

- przerwanej lub zaniechanej przed wdrożeniem innowacji.

Po drugie, charakterystyczne w przypadku działalności innowacyjnej jest to, że aby określić ją tym mianem, działania wchodzące w jej skład i z nią związane nie muszą zawierać elementów nowości. Warunkiem wystarczającym jest, żeby przyczyniały się do powstania innowacji rozumianej jako rezultat wcześniej podjętych czynności. Tak więc nie jest wymagane, aby działania składające się na aktywność innowacyjną z zakresu naukowego, technicznego, organizacyjnego finansowego czy komercyjnego wyróżniały się charakterem innowacyjnym (Głuszczuk 2016, s. 75). Innowację rozumianą jako rezultat należy natomiast traktować jako nowości produktowe, procesowe, a także organizacyjne czy mar- 
ketingowe (Oslo Manual, 2005, s. 46). A.A. Ferraresi i inni (2012, p. 690) innowację interpretują jako proces przekształcania wiedzy $\mathrm{w}$ wartość przez zastosowanie nowych lub udoskonalanie istniejących produktów, procesów oraz systemów. Czynności te wpływają na sprawne i efektywne zarządzanie organizacją. Niezależnie od sposobu interpretowania innowacji i jej rodzaju - czy wynika ona $\mathrm{z}$ naśladownictwa, czy też jest zupełnie nowym rozwiązaniem - żeby została ona uznana za rezultat, musi zostać spełniony warunek implementacji (produktu/procesu) lub nowa metoda marketingowa/ organizacyjna musi zostać wykorzystana w działalności przedsiębiorstwa. Warto w tym miejscu dodać, że nowe wydanie podręcznika Oslo Manual (2018, s. 71-75) klasyfikuje innowacje tylko do dwóch grup: innowacje produktowe oraz tzw. innowacje w zakresie procesów biznesowych. Pierwsza grupa odpowiada innowacjom produktowym z poprzedniej edycji podręcznika, dodaje się natomiast w niej wzory wyrobów czy usług, które były wcześniej zaliczane do innowacji marketingowych. $\mathrm{W}$ grupie innowacji związanych z procesami biznesowymi wyróżnia się zarówno funkcje biznesowe przedsiębiorstwa związane $\mathrm{z}$ wytwarzaniem produktów, w tym także usług, jak i zmiany w zakresie funkcji wspierających procesy produkcyjne, takie jak: marketing, obsługa posprzedażna, funkcje zarządzania czy administracyjne, logistyka, dystrybucja, technologia informacyjno-telekomunikacyjna (ICT).

Prowadzona działalność innowacyjna lub prace w zakresie wdrażania nowości zaniechane, kontynuowane lub też zakończone sukcesem $\mathrm{w}$ postaci innowacji świadczą o innowacyjności przedsiębiorstwa, która jest atrybutem różnicującm podmioty rynkowe. Przez wielu autorów (Hee-Jae Cho, Pucik, 2005, s. 556) utożsamiana jest ona $\mathrm{z}$ innowacjami. Dominuje jednak pogląd, że innowacyjność jest zdolnością do wprowadzania innowacji technologicznych bądź nietechnologicznych, która jest wymierna oraz możliwa do oceny. Jest to zdolność do tworzenia czegoś nowego lub wprowadzania znaczących zmian, działanie w sposób, który wykorzystuje tę zdolność (Hilami i in., 2010, s. 557). Innowacyjność przedsiębiorstwa można rozumieć także jako atrybut umożliwiający konkurowanie w sytuacji, gdy przewaga konkurencyjna firmy opiera się na innowacjach (Hult i in., 2004, s. 429).

Prowadzenie działalności innowacyjnej, a także proces koncepcji oraz wdrażania innowacyjnych rozwiązań w podmiotach gospodarczych stanowi duże wyzwanie. Wiąże się z ryzykiem, a także koniecznością angażowania znaczących zasobów wiedzy i zasobów finansowych, co $\mathrm{z}$ perspektywy szczególnie najmniejszych przedsiębiorstw stanowi barierę wzrostu innowacyjności. Bezdyskusyjny jest jednak pozytywny wpływ tworzenia wartości przez innowacje na funkcjonowanie oraz rozwój przedsiębiorstwa, a także na przetrwanie na konkurencyjnym rynku (Lee i in., 2012, s. 822-823; Cefis, Marsili, 2006, s. 629). W celu zniwelowania tych ograniczeń takie kraje, jak Szwajcaria, Szwecja, Dania czy Finlandia (Hollanders, Es-Sadki, 2017, s. 18), liderujące pod względem innowacyjności, a także inne państwa rozwinięte, stosują politykę kreowania i wsparcia innowacji. Zastosowanie w jej ramach mają różne metody oraz instrumenty, które oddziałują na sferę społeczno-gospodarczą, a w szczególności na ośrodki naukowo-badawcze oraz przedsiębiorstwa. Jednym $\mathrm{z}$ takich narzędzi są opracowane - Regionalne Strategie Innowacyjności RSI poszczególnych województw, które ze względu na niezadowalający poziom innowacyjności polskich regionów (w porównaniu do pozostałych obszarów krajów Unii Europejskiej), stają się znaczące $\mathrm{w}$ procesie wsparcia, kreowania, absorpcji i dyfuzji innowacji. RSI opracowywane w wyniku analiz prowadzonych w każdym z polskich województw w znacznej mierze bazują oraz podporządkowane są rozwojowi w ramach tzw. inteligentnych specjalizacji - smart specialisation (Brzóska, 2014, s. 42).

Koncepcja inteligentnych specjalizacji po raz pierwszy została zaprezentowana przez członków grupy eksperckiej badającej transatlantycką lukę produktywności (McCann, Ortega-Argilés, 2015, s. 1292 za: Foray i in., 2009). Do dziś nie ma jednoznacznych poglądów, co tak nadzwyczajnego charakteryzuje inteligentne specjalizacje (Foray $\mathrm{i}$ in., 2011, s. 1). Specjalizacja regionów, a także państw jest w obrębie zainteresowań badaczy od kilkuset lat (Kardas, 2011, s. 122-124). Kryterium wyboru i różnicowania specjalizacji w ujęciu regionalnym powinien być potencjał regionu zarówno instytucjonalny, jak i technologiczny, uwzględniający stan obecny, a także prognozujący procesy rozwojowe w przyszłości. Proces wyboru powinien bazować na ocenach ilościowych oraz jakościowych i być realnie dopasowany do możliwości, zdolności i potrzeb w regionie (Przegląd regionalny ..., 2008, s. 30-48). Wybór inteligentnej specjalizacji to dokładna diagnoza, ale również wizja możliwości jego rozwoju. W procesie wyboru specjalizacji uwzględnić należy kontekst dynamiki otoczenia krajowego oraz uwarunkowania globalne (Prahald, Krishnan, 2008, s. 15).

W literaturze wymienia się cztery założenia inteligentnej specjalizacji, do których zalicza się (Kardas, 2011, s. 127):

- utworzenie obszaru badań i innowacji umożliwiającego rywalizację między wieloma konkurentami - lepsze wykorzystanie efektu skali, zakresu i rozprzestrzeniania,

- konkurencję między regionami europejskimi w tych samych dziedzinach nauki, która spowoduje brak osiągnięcia założonego celu z uwagi na brak odpowiedniej masy krytycznej,

- sposób implementacji inteligentnej specjalizacji, w których głównymi uczestnikami są przedsiębiorcy, a szczególna rola wspierająca należy do administracji publicznej,

- istotę koncepcji inteligentnej specjalizacji określaną jako tzw. technologie ogólnego zastosowania (General Purpose Technologies), wykorzystywane w wielu obszarach aktywności człowieka.

Jak wspomniano wcześniej, inteligentne specjalizacje mogą mieć dwa wymiary - krajowy oraz regionalny. W literaturze (OECD, 2013, s. 23) wskazuje się jednak na 
osłabienie krajowego systemu innowacji jako jednostki kształtującej politykę regionalnych systemów innowacji i wzrost globalnych sieci innowacji. Dostrzega się także tendencje do przekazywania odpowiedzialności za innowacje na poziomy regionów. W związku z tym, w regionalnym ujęciu w smart specialisation bazuje się na relacjach między nauką, sferą publiczną, edukacją oraz biznesem (Stawicki, Wojnicka-Sycz, 2014, s. 9). W kontekście takich zależności podstawowym warunkiem rozwoju inteligentnych specjalizacji jest wykorzystanie potencjału regionu przez możliwie najlepsze dopasowanie kierunków rozwoju nauki oraz kształcenia do jego specyfiki gospodarczej i społecznej (Brzóska, 2014, s. 43). Na powiązania innowacyjnych technologii oraz inteligentnych specjalizacji wskazuje się w opracowaniu $\operatorname{OECD}(2013$, s. 23). Zgodnie z nim, inteligentna specjalizacja, a także ramy polityczne stanowią nowe możliwości do osiągnięcia celów związanych z ograniczeniami fiskalnymi i inwestycjami w długoterminowy potencjał wzrostu z perspektywy gwałtownych zmian technologicznych oraz globalizacji.

Inteligentna specjalizacja w perspektywie innowacyjności to nowy kierunek rozwoju gospodarczego zwrócony w stronę polityki badawczej i innowacyjnej, który wykracza poza klasyczne inwestycje w badania i technologie oraz ogólne kreowanie potencjału w zakresie innowacyjności (Panorama inforegio). Obejmuje proces tworzenia wizji, identyfikacji przewagi konkurencyjnej, ustalania priorytetów strategicznych i wykorzystania inteligentnych polityk w celu maksymalizacji opartego na wiedzy potencjału rozwoju każdego regionu, silnego lub słabego, high-tech i low-tech (The Role of Universitie ...,
2014, s. 8). Podczas procesu kreowania trwałych przewag konkurencyjnych najwartościowszym potencjałem regionu, decydującym o jego unikalności, są niepowtarzalne i specyficzne zasoby (Jewtuchowicz, 2009, s. 10; Nowakowska, 2008, s. 46-47). Przedsiębiorstwa jako składowa gospodarki danego regionu stanowią również element inteligentnej specjalizacji. Decydują o niej nie tylko wdrażane innowacje technologiczne, ale również społeczne czy marketingowe (Słodowa-Chełpa, 2013, s. 93-94). Z tego względu, a także $z$ uwagi na metodologię dotyczącą badań nad innowacyjnością, w opracowaniu wśród innowacyjnych mikroprzedsiębiorstw uwzględniono zarówno te, które wdrożyły nowości technologiczne, jak i nietechnologiczne (organizacyjne, marketingowe).

\section{Działalność innowacyjna mikroprzedsiębiorstw reprezentujących inteligentne specjalizacje - wyniki badań}

$\mathbf{N}$ a podstawie przeprowadzonych badań własnych zauważono, że większość mikropodmiotów, reprezentujących inteligentne specjalizacje województwa warmińsko-mazurskiego, miała charakter innowacyjny - 54,9\% (rys. 1). Pozostała grupa były to firmy, które w badanym trzyletnim okresie nie wdrożyły innowacji technologicznych ani nietechnologicznych, a zatem nie zostały uznane za innowacyjne.

W wynikach badań PARP (Tarnawa, 2015, s. 49) dotyczących polskich mikroprzedsiębiorstw dostrzec można, że większość mikrofirm wprowadzała innowacje. Wystąpiła więc taka sama sytuacja, jaką zaobserwowano w badaniach

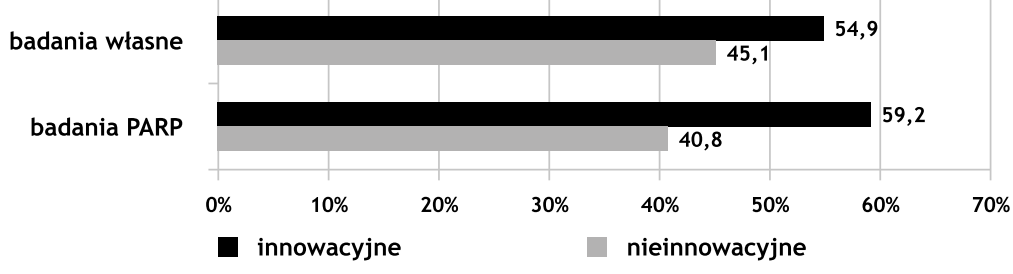

Rys. 1. Poziom innowacyjności mikroprzedsiębiorstw inteligentnych specjalizacji (\%) Źródło: opracowanie własne na podstawie badań empirycznych oraz Tarnawa, 2015, s. 49

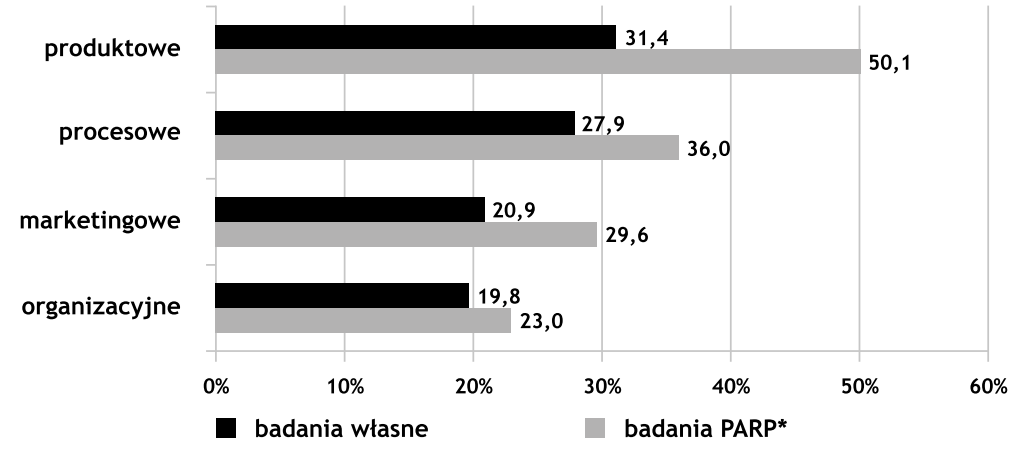

Rys. 2. Rodzaj wdrożonych innowacji (\%)

Źródło: opracowanie wtasne na podstawie badań empirycznych oraz Tarnawa, 2015, s. 50

* dane pochodzą z pytań wielokrotnego wyboru - wartości procentowe nie sumują się do 100 
własnych - przewaga innowacyjnych podmiotów nad nieinnowacyjnymi. Porównując wyniki badań, można stwierdzić, że poziom innowacyjności mikroprzedsiębiorstw jest zadowalający, a nie tak jak przyjęło się określać - niski. Stan taki był wynikiem tego, że w badaniach prowadzonych przez Główny Urząd Statystyczny (GUS) oraz wielu innych opracowaniach prowadzonych $\mathrm{w}$ obszarze innowacyjności, do przedsiębiorstw innowacyjnych nie zalicza się tych, które wprowadziły innowacje nietechnologiczne (organizacyjne lub marketingowe). W badaniach własnych natomiast za podmioty te uznawano jednostki, które wprowadziły w okresie badanym przynajmniej jedną innowację bez względu na to, czy miała ona charakter technologiczny czy też nie.

Wśród innowacyjnych mikroprzedsiębiorstw inteligentnych specjalizacji, które zostały objęte badaniami, największy odsetek stanowiły nowości technologiczne, czyli produktowe oraz procesowe - odpowiednio 31,4 i 27,9\%, łącznie 59,3\% (rys. 2). Pozostałe 40,7\% innowacji były to zmiany nietechnologiczne wprowadzone po raz pierwszy do praktyki działania firmy - marketingowe $20,9 \%$ i organizacyjne $19,8 \%$ spośród wszystkich wprowadzonych innowacji.

W kontekście przedstawionych wyników badań trzeba zaznaczyć, że do innowacji produktowych i procesowych zaliczono nie tylko zupełnie nowe rozwiązania, ale również znaczące ulepszenia w ich zakresie. Tak więc poprawa stosowanej technologii produkcyjnej albo znaczące ulepszenie produktu, wynikające z poprawy parametrów technicznych, zastosowania lepszych komponentów czy materiałów uznawane było za innowację. Takie podejście zgodne jest $\mathrm{z}$ tym prezentowanym w podręczniku Oslo Manual (2008, s. 155), w którym innowacjami są również ulepszenia powstałe w zakresie innowacji technologicznych. Wyniki badań własnych były zbieżne z prowadzonymi w PARP (Tarnawa 2015, s. 50). W tym przypadku również największy udział stanowiły innowacje technologiczne, a wśród nich produktowe - 50,1\%. Najmniejszy odsetek przedsiębiorstw wprowadziło nowości organizacyjne - 23,0\%.

Znaczące zmiany występujące $\mathrm{w}$ dotychczasowych produktach lub procesach, określane mianem ulepszeń, powodują jednak, że podczas oceny poziomu innowacyjności również na nie należy zwrócić uwagę. W badaniach realizowanych $\mathrm{w}$ mikroprzedsiębiorstwach inteli- gentnych specjalizacji dostrzeżono, że modernizowane produkty i procesy przeważały nad zupełnie nowymi rozwiązaniami w tym zakresie (rys. 3). Zjawisko to należy uznać za negatywne, gdyź świadczy o tym, że innowacje wprowadzane w badanym okresie miały częściej charakter odtwórczy niż twórczy. Były więc one wynikiem działań naśladujących konkurencję lub też impulsywną odpowiedzią na często zmieniające się zapotrzebowanie strony popytowej rynku. Zaledwie 13,6\% nowości produktowych i tylko $11,6 \%$ procesowych miało charakter twórczy (łącznie 25,2\%). Podczas gdy ulepszeń technologicznych było aż o 8,9 punktu procentowego więcej $-34,1 \%$.

W tak zaprezentowanym zestawieniu największy odsetek wśród badanych mikrofirm stanowiły zmiany nietechnologiczne, w tym po raz pierwszy wprowadzone do praktyki przedsiębiorstwa innowacje marketingowe - 20,9\%, a na drugim miejscu pierwsze zastosowania rozwiązań organizacyjnych - 19,8\%. Przedstawione szczegółowe wyniki dotyczące rodzajów wdrażanych innowacji są niekorzystnym zjawiskiem, na które mikroprzedsiębiorcy regionu Warmii i Mazur w przyszłości powinni zwrócić uwagę. Badania dostarczyły informacji na temat konieczności zintensyfikowania oryginalnych prac twórczych (kosztem odtwórczych) prowadzonych przez mikropodmioty reprezentujące inteligentne specjalizacje województwa warmińsko-mazurskiego. W badaniach PARP prowadzonych na skalę krajową nie dokonano rozgraniczenia innowacji na zupełne nowości oraz ulepszenia, a więc nie było możliwe porównanie tych wyników $\mathrm{z}$ rezultatami uzyskanymi $\mathrm{w}$ badaniach własnych.

W celu dokonania kompleksowej oceny poziomu innowacyjności mikroprzedsiębiorstw inteligentnych specjalizacji konieczna była również analiza stopnia nowości wdrażanych rozwiązań innowacyjnych (rys. 4). Wyniki w tym zakresie prezentowały się pozytywnie. Pierwszym dowodem świadczącym o tym jest fakt, że w mikrofirmach z regionu Warmii i Mazur przeważały innowacje, które zostały uznane za nowości w skali powiatu - 48,2\%. Kolejnym powodem, na podstawie którego można wnioskować o wysokim poziomie wdrożonych innowacji, było występowanie nowości w skali europejskiej i światowej-3,1\%. Chociaż był to niewielki odsetek, to jednak w przypadku mikropodmiotów już

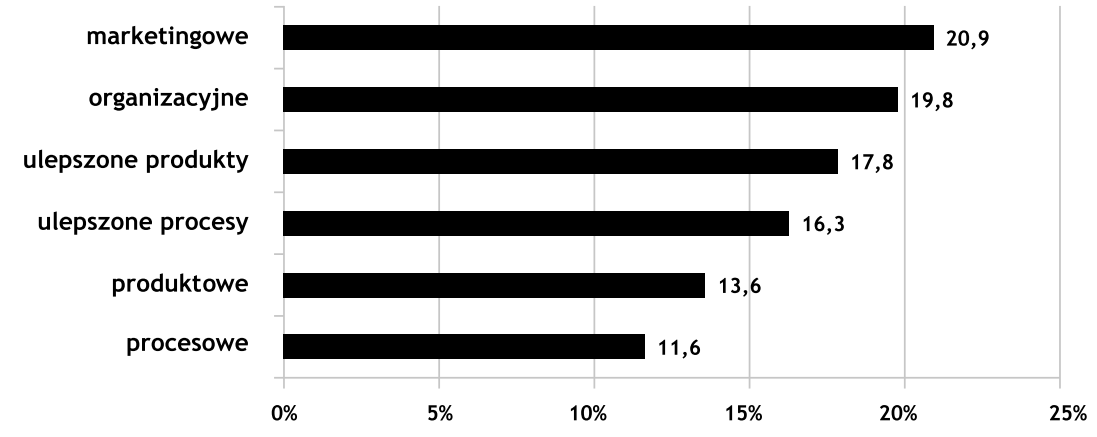

Rys. 3. Rodzaj wdrożonych innowacji z uwzględnieniem stopnia ich nowości (\%) Źródto: opracowanie wtasne 


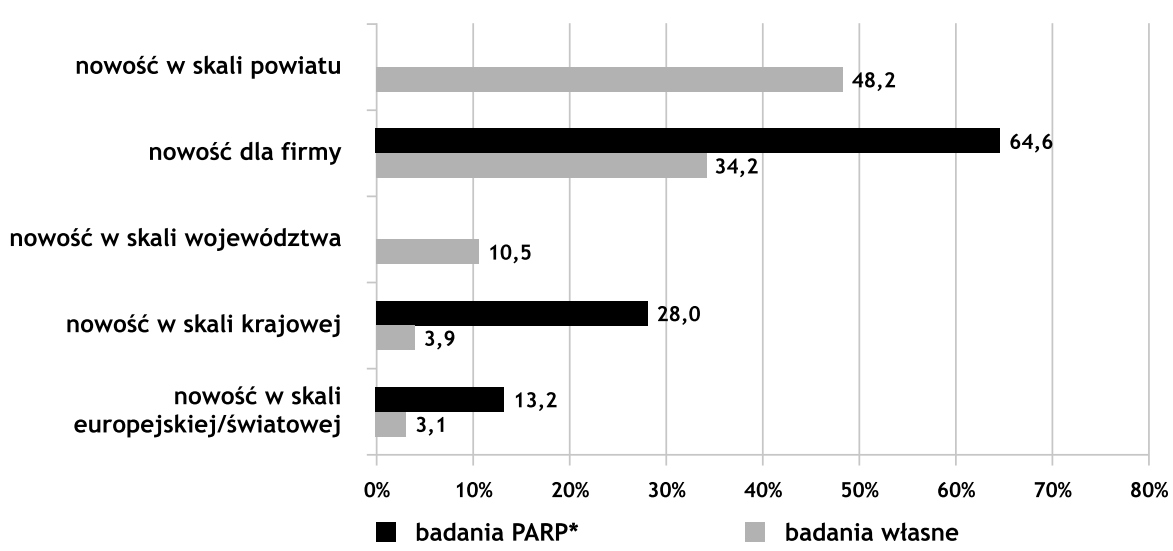

Rys. 4. Skala nowości wdrożonych innowacji (\%)

Źródło: opracowanie własne na podstawie badań empirycznych oraz Tarnawa, 2015, s. 51

sama działalność na obszarze zagranicznym jest znacznym wyzwaniem i sukcesem. W firmach działających na rynku globalnym innowacyjność ma odzwierciedlenie w kreowaniu nowych produktów oraz poprawie skuteczności działania (Sipa, 2011, s. 444). Ostatnią przesłanką, która pozwoliła na pozytywne dedukowanie na temat innowacyjności w zakresie badanych podmiotów, było porównanie ich $\mathrm{z}$ ogólnopolskimi wynikami przeprowadzonymi przez PARP (Tarnawa, 2015, s. 51).

\section{Podsumowanie}

C harakteryzując grupę badawczą warmińsko-mazurskich mikroprzedsiębiorstw reprezentujących inteligentne specjalizacje, należy wskazać, że większość stanowiły podmioty innowacyjne, wśród których najwięcej wdrożono nowości technologicznych, a najpopularniejszymi $\mathrm{z}$ nich były te o charakterze produktowym. Zbieżna sytuacja wystąpiła w badaniach prowadzonych przez PARP. Podczas analizy poziomu działalności innowacyjnej dostrzeżono zarówno zjawiska pozytywne, jak i negatywne. Do tych drugich zaliczyć należy dominację ulepszeń nad zupełnymi nowościami. Dodatkowo, podczas rozgraniczenia innowacji technologicznych na ulepszenia oraz zupełne nowości zauważono, że w największej liczbie mikrofirmy wdrażały nowości będące innowacjami marketingowymi, a następnie organizacyjnymi (grupa nowości nietechnologicznych). Wnioskować można zatem, że innowacje technologiczne wprowadzane przez mikroprzedsiębiorstwa inteligentnych specjalizacji regionu Warmii i Mazur miały bardziej charakter odtwórczy niż zupełnych nowości. Zjawisko to świadczy o dostosowawczym sposobie prowadzenia działalności innowacyjnej i koncentrowaniu się głównie na innowacjach produktowych i procesowych mających postać ulepszeń (porównanie $\mathrm{z}$ badaniami PARP nie było możliwe w tym zakresie badań).

W odniesieniu do działalności innowacyjnej (w badaniach własnych) dostrzeżono jednak więcej jej pozytywnych niż negatywnych aspektów. Na takie stwierdzenie pozwolił, po pierwsze, zidentyfikowany (wspomniany wcześnie) w badaniach większy odsetek firm innowacyj- nych niż nieinnowacyjnych, a po drugie, poziom nowości wdrażanych innowacji (dominujące były nowości na skalę powiatu). W kontekście drugiego $\mathrm{z}$ wymienionych aspektów wyniki uzyskane przez mikroprzedsiębiorstwa $\mathrm{z}$ Warmii i Mazur prezentowały się zdecydowanie korzystniej niż miało to miejsce w badaniach ogólnopolskich. Wśród warmińsko-mazurskich podmiotów dominowały bowiem jednostki wprowadzające rozwiązania będące nowością na skalę powiatu, zaś w odniesieniu do danych PARP najwięcej firm stworzyło innowacje będące nowością dla nich samych. Trzecim przejawem świadczącym o pozytywnym poziomie działalności innowacyjnej badanych mikroprzedsiębiorstw był brak zależności (która charakteryzowała mikrofirmy z grupy badawczej PARP i która dominuje od wielu lat), zgodnie z którą wraz ze wzrostem zasięgu rynku malał poziom innowacji wdrażanych. Ostatnim pozytywnym symptomem i przejawem innowacyjności warmińsko-mazurskich mikroprzedsiębiorstw było prowadzenie przez nie działalności innowacyjnej na rynkach europejskich i światowych w postaci wdrażania na nich nowych rozwiązań w zakresie każdego z czterech rodzajów innowacji.

Podsumowując, zaprezentowane wnioski pozwoliły na pozytywne zweryfikowanie postawionej $\mathrm{w}$ opracowaniu hipotezy badawczej, w zakresie której zakładano, że poziom działalności innowacyjnej podmiotów reprezentujących inteligentne specjalizacje jest wyższy niż ten reprezentowany przez podmioty mikro z całej Polski. Należy zaznaczyć w tym miejscu, że wyższy poziom działalności innowacyjnej mikroprzedsiębiorstw z Warmii i Mazur może wynikać $\mathrm{z}$ tego, że reprezentowały one inteligentne specjalizacje, które są preferowane $\mathrm{np}$. $\mathrm{w}$ pozyskiwaniu funduszy z programów unijnych na innowacje.

$\mathrm{W}$ celu poprawy poziomu działalności innowacyjnej warmińsko-mazurskie mikropodmioty powinny zwrócić uwagę szczególnie na dominację tworzenia, a nie imitowania innowacji (ulepszenia). Do osiągnięcia tego założenia pomocne na pewno będzie zrozumienie przez przedsiębiorców korzyści płynących ze stałego, a nie jednorazowego, wdrażania innowacji. Omawiane w opracowaniu badania przeprowadzone zostały na reprezentatywnej grupie mikroprzedsiębiorstw wyliczonej dla województwa warmińsko-mazurskiego. Materiał 
badawczy nie ma zatem charakteru statystycznego i nie może być podstawą do formułowania wniosków dotyczących sektora mikroprzedsiębiorstw w kraju, jednakże może stanowić pewien punkt odniesienia w pogłębionych badaniach nad tą problematyką.

\section{dr Kamil Decyk \\ Uniwersytet Warmińsko-Mazurski w Olsztynie \\ Wydział Nauk Ekonomicznych \\ ORCID: 0000-0002-8590-4185 \\ e-mail: kamil.decyk@uwm.edu.pl}

\section{Przypis}

1) Grupa reprezentatywna oznacza, że przebadano wystarczającą liczbę podmiotów, aby na podstawie wyników badań wnioskować na temat poziomu działalności innowacyjnej w ramach całej populacji mikroprzedsiębiorstw z województwa warmińsko-mazurskiego. Założono błąd oszacowania na poziomie 5\% i poziomie ufności $95 \%$ dla populacji o liczebności skończonej 114144 mikropodmiotów.

\section{Bibliografia}

[1] Brzóska J. (2014), Inteligentne specjalizacje regionu jako szansa wzrostu innowacyjności przedsiębiorstwa. „Studia Ekonomiczne", Nr 183(1), s. 38-48.

[2] Cefis E., Marsili O. (2006), Survivor: The Role of Innovation in Firms' Survival, „Research Policy”, Vol. 35, No. 5, pp. 626-641.

[3] Ferraresi A.A., Quandt C.O., dos Santos S.A., Frega J.R. (2012), Knowledge Management and Strategic Orientation: Leveraging Innovativeness and Performance, „Journal of Knowledge Management", Vol. 5, pp. 688-701.

[4] Foray D., David P.A., Hall B. (2009), Smart Specialisation - The Concept, „Knowledge Economists Policy Brief”, No. 9, June 2009, pp. 1-5, http://ec.europa.eu/invest-in-research/pdf/download_en/kfg_policy_brief_no9.pdf?11111.

[5] Foray D., David P., Hall B. (2011), Smart Specialization. From Academic Idea to Political Instrument, the Surprising Career of a Concept and the Difficulties Involved in its Implementation, MTEI Working Paper 2011-01, pp. 1-16, École Polytechnique Fédérale de Lausanne, Loznanna.

[6] Głuszczuk D. (2016), Problem pomiaru działalności innowacyjnej przedsiębiorstw na poziomie regionów, Prace Naukowe Uniwersytetu Ekonomicznego we Wrocławiu, Nr 433, s. 73-81.

[7] Hee-Jae Cho, Pucik V. (2005), Relationship between Innovativeness, Quality, Growth, Profitability, and Market Value, „Strategic Management Journal”, Vol. 26, pp. 555-575.

[8] Hilami M.F., Ramayah T., Mustapha Y., Pawanchik S. (2010), Product and Process Innovativeness: Evidence from Malaysian SMEs, „European Journal of Social Science”, Vol. 16, No. 4, pp. 547-555.

[9] Hollanders H., Es-Sadki N. (2017), Regional Innovation Scoreboard, MERIT, European Union.

[10] Hult G.T.M., Hurley R.F., Knight G.A. (2004), Innovativeness: Its Antecedents and Impact on Business Perfor- mance, „Industrial Marketing Management”, Vol. 33, pp. 429-438.

[11] Janasz W., Kozioł K. (2007), Determinanty działalności innowacyjnej przedsiębiorstw, PWE, Warszawa.

[12] Jewtuchowicz A. (2009), Terytorium jako podstawa procesu tworzenia innowacyjnych środowisk przedsiębiorczości, [w:] A. Nowakowska (red.), Budowanie zdolności innowacyjnych regionów, Wydawnictwo Uniwersytetu Łódzkiego, Łódź, s. 9-17.

[13] Kardas M. (2011), Inteligentna specjalizacja - (nowa) koncepcja polityki innowacyjnej, Optimum, „Studia Ekonomiczne", Nr 2(50), s. 124-138.

[14] Kurek-Kokocińska S. (2002), O metodologię badań porównawczych czasopism bibliotekoznawczych i informacyjnych, „Zagadnienia Informacji Naukowej”, Nr 2, s. 53-59.

[15] Lee S.M., Olson D.L., Trimi S. (2012), Co-innovation: Convergenomics, Collaboration, and Co-creation for Organizational Values, „Management Decision”, Vol. 5, pp. 817-831.

[16] McCann P., Ortega-Argilés R. (2015), Smart Specialisation, Regional Growth and Applications to EU Cohesion Policy, „Journal Regional Studies": Issue 8: Place-based Economic Development and the New EU Cohesion Policy, Vol. 9, pp. 1291-1302.

[17] Nowakowska A. (2008), Dobrze zarządzać to zrozumieć „własne podwórko”, „Pomorski Przegląd Gospodarczy”, temat numeru: Dobre rządzenie, Nr 2(37), s. 46-48.

[18] OECD. (2013), Innovation-driven Growth in Regions: The Role of Smart Specialisation, Preliminary version.

[19] Oslo Manual. Guidelines for Collecting and Interpreting Innovation Data, Third Edition (2005), OECD \& Eurostat Publications Service, Paryż.

[20] Oslo Manual. Guidelines for Collecting, Reporting and Using Data on Innovation, 4th Edition (2018), OECD.

[21] „Panorama inforegio” (2012), https://ec.europa.eu/regional_policy/sources/docgener/panorama/pdf/mag44/ mag44_pl.pdf, s. 8-13, data dostępu: 15.01 .2018 r.

[22] Pieter J. (1967), Ogólna metodologia pracy naukowej, Zakład Narodowy im. Ossolińskich “Ossolineum”, Wrocław.

[23] Prahalad C.K., Krishnan M.S. (2008), New Age of Innovation, McGraw-Hill.

[24] Przegląd regionalny. Doświadczenia i szanse regionów (2008), Ministerstwo Rozwoju Regionalnego, Warszawa.

[25] Schumpeter J.A. (1960), Teoria rozwoju gospodarczego, PWN, Warszawa.

[26] Schumpeter J.A. (1995), Socjalizm. Kapitalizm. Demokracja, Wydawnictwo Naukowe PWN, Warszawa.

[27] Sipa M. (2011), Specyfika działalności małych przedsiębiorstw o zróżnicowanym poziomie innowacyjności i konkurencyjności, [w:] A. Bielawska (red.), Uwarunkowania rynkowe rozwoju mikro, małych i średnich przedsiębiorstw - mikrofirma 2011. Tworzenie i zarzadzanie, Wydawnictwo Naukowe Uniwersytetu Szczecińskiego, Szczecin, s. 441-448.

[28] Słodowa-Chełpa M. (2013), Inteligentna specjalizacja polskich regionów, „Roczniki Nauk Społecznych”, Tom 5(41), Nr 1, s. 87-120. 
[29] Stawasz E., Niedbalska D. (2011), Przedsiębiorstwo innowacyjne, [w:] K.B. Matusiak (red.), Innowacje i transfer technologii. Stownik pojęć, Wydawnictwo PARP, Warszawa, s. 54-56.

[30] Stawicki M., Wojnicka-Sycz E. (2014), Wyznaczanie, monitoring $i$ ewaluacja inteligentnych specjalizacji, Wydawca Maciej Stawicki, Warszawa.

[31] Szatkowski K. (2001), Ekonomiczne uwarunkowania działalności innowacyjnej, [w:] M. Brzeziński (red.), Zarzadzanie innowacjami technicznymi i organizacyjnymi, Difin, Warszawa.

[32] Szreder M. (2004), Metody i techniki sondażowych badań opinii, PWE, Warszawa.

[33] Tarnawa A. (2015), (Nie)oczekiwana mikroinnowacyjność, [w:] P. Zadura-Lichota (red.), Innowacyjna przedsiębiorczość w Polsce. Odkryty i ukryty potencjał polskiej innowacyjności, Wydawnictwo PARP, Warszawa, s. 47-62.

[34] The Role of Universities and Research Centres as Drivers for Smart Specialisation at Regional Level (2014), European Commission Directorate-General for Research and Innovation.

[35] Wspólne obszary inteligentnych specjalizacji województw Polski Wschodniej (2015), Ministerstwo Infrastruktury, Departament Programów Ponadregionalnych, Warszawa.
Innovation Activity Level of Microenterprises from Smart Specialisations - the Perspective of Warmińsko-Mazurskie Voivodeship

\section{Summary}

The aim of the research was to assess innovation activity level of microenterprises operating in smart specializations. Innovation activity level should be assessed as satisfactory and at the same time more favourable compared to national entities. In most cases, micro enterprises were innovative, they introduced technological innovations, especially product ones. The changes implemented by these companies were novelties on the county scale. On the other hand, the unfavourable percentage of improvements was presented, which was higher in comparison to the whole technological novelties.

\section{Keywords}

smart specializations, innovation activity, innovativeness, microenterprise 